\title{
FINANCIAL INCLUSION IN BANGLADESH: POLICY RECOMMENDATIONS FOR MODIFIED UNIT BANKING SYSTEM
}

\author{
Corresponding Author: \\ Hossain Mohammed Omar Khayum \\ Department of Development Studies \\ Faculty of Social Sciences \\ University of Dhaka \\ Dhaka, Bangladesh \\ Primary Email: omar.tamim1993@gmail.com \\ Institutional Email: hmomarkhayum@student.bup.edu.bd \\ Contact no: +8801796248623
}

\begin{abstract}
Co- Author:
Noshin Tasneem

Articled Student

The Institute of Chartered Accountants of Bangladesh (ICAB)

Dhaka, Bangladesh

Email: noshintasneem@ymail.com
\end{abstract}




\title{
Financial Inclusion in Bangladesh: Policy Recommendations for Modified Unit Banking System
}

\begin{abstract}
The financial inclusion, including all the people with the finance, is very concerned issue all over the world where Bangladesh is also trying to include all the people with the finance. Bangladesh lies in such a group of countries where only $17.6 \%$ - $38.6 \%$ adults are presently under the reach of the formal financial services. This is because the present banks and other formal financial modes consider the outcome and profitability in a way that, the rural and non-developed areas are always out of the consideration. But these areas consist of the most population of Bangladesh. And only then financial inclusiveness will be successful in Bangladesh when people from these regions will be under formal financial consideration. The paper seeks for a solution to the issue and presents the Unit Banking System as a probable way towards financial inclusion. For implementing the system in Bangladesh, the system needs a slight modification to cope in Bangladeshi economic condition and address the specific needs without hampering the surroundings. Considering all these, the paper shows the status, problems and key points of financial scenario of inclusion in Bangladesh and shows policy for a Modified Unit banking System.
\end{abstract}

Keywords: Financial Inclusion, Unit Banking, Banking in Bangladesh, Banking policy.

JEL Classification: E02, E44, E61, G21 


\section{Introduction}

Poverty is more than just a lack of money. It involves a lack of access to the instruments and means through which the poor could improve their lives. Exclusion from the formal financial system has increasingly been identified as one of the barriers to a world without poverty. In many developing countries, more than half of households lack an account with a financial institution, while small firms frequently cite difficulty in accessing and affording financing as a key constraint on their growth. Financial exclusion is the inability, difficulty or reluctance to access appropriate, so-called mainstream, financial services. The reduction of financial exclusion is a priority for the present government because it can lead to social exclusion. People outside the mainstream financial services suffer financial disadvantages including: higher-interest credit; lack of insurance; no account into which income can be paid; and higher-cost utilities. Those particularly vulnerable to financial exclusion include: housing association tenants; young people not in employment, education or training; those leaving care; lone parents and divorced people; disabled people, those with mental health problems; people living in isolated or disadvantaged areas; prisoners, ex-offenders and families of prisoners; members of ethnic minorities; migrants; asylum seekers and refugees; homeless people; older people; women; people with a Post Office Card Account or basic bank account; people with low incomes. Much financial exclusion is caused by a complex set of factors. Consequently, financial exclusion initiatives must address many different issues. These include: geographical exclusion e.g. resulting from branch closures; failure to qualify because of poor credit history or problems in supplying identity document requirements; the relative cost of financial products and services e.g. charges for unauthorized overdrafts; and cultural and psychological barriers.

Moreover there are people with bank accounts may barely use them, preferring to withdraw all their money each week and manage it as cash.

On the other hand, financial inclusion refers to a process that ensures the ease of access, availability and usage of the formal financial system for all members of an economy. An inclusive financial system has several merits. It facilitates efficient allocation of productive resources and thus can potentially reduce the cost of capital. In addition, access to appropriate financial services can significantly improve the day-to-day management of finances. An inclusive financial system can help in reducing the growth of informal sources of credit (such as 
money lenders), which are often found to be exploitative. Thus, an all-inclusive financial system enhances efficiency and welfare by providing avenues for secure and safe saving practices and by facilitating a whole range of efficient financial services.

The importance of an inclusive financial system is widely recognized in the policy circle and recently financial inclusion has become a policy priority in many countries. Initiatives for financial inclusion have come from the financial regulators, the governments and the banking industry. But those are not enough according to the previous studies. Here in this study we should explore through the probable options which can assist the present policies to achieve a greater financially inclusive economy.

\section{Objective of the Study}

The objectives of the study are as follows:

1. To study the reasons behind financial exclusion and importance of financial inclusion.

2. To present the scenario of banking and financial inclusion of Bangladesh.

3. To recommend policies for a better financially inclusive economy in Bangladesh.

4. To present the modified unit banking system as a solution to the present problems of Bangladesh regarding financial exclusion.

\section{Research Problem}

Despite the considerable progress made by microfinance institutions, credit unions, and savings cooperatives over the last two decades, the majority of the world's poor remain unserved by formal financial intermediaries that can safely manage cash and intermediate between net savers and net borrowers. According to the Consultative Group to Assist the Poor (CGAP), the absolute number of savings accounts worldwide is reported to exceed the global population (CGAP 2009). And yet half of the world's adult population — 2.5 billion people — does not, in fact, have access to savings accounts and other formal financial services (Chaia et. al. 2009).

The scenario is not much deviated in Bangladesh. It seems that, though the present banking system and structure is performing very well in terms of profitability and others, it fails to serve for an inclusive economic purpose. This study is to find a way out of the economic hindrance. 
Researches have been done by many researchers regarding financial exclusion, its problems, devastating natures and about the solutions to the problem. There are quite a good number of research works done by different researchers, Bangladesh Bank, Bangladesh Government and so on regarding the problem and prospects of different modes of financial inclusion in Bangladesh. However, the researchers didn't address the problem with the view to addition of any other banking system along with the present one to tackle the problem. Also there are not enough research works done even in the field of Unit Banking System let alone its modification, implication and prospects in Bangladeshi Economy. This study is a very small initiative targeting the vast study gap.

\section{Review of Literature}

Literature on financial exclusion has defined it in the context of a larger issue of social exclusion of certain groups of people from the mainstream of the society. Leyshon and Thrift (1995) define financial exclusion as referring to those processes that serve to prevent certain social groups and individuals from gaining access to the formal financial system. Carbo et al. (2005) have defined financial exclusion as broadly the inability (however occasioned) of some societal groups to access the financial system. According to Conroy (2005), financial exclusion is a process that prevents poor and disadvantaged social groups from gaining access to the formal financial systems of their countries. According to Mohan (2006) financial exclusion signifies the lack of access by certain segments of the society to appropriate, low-cost, fair and safe financial products and services from mainstream providers.

In the case of credit, the proper definition of the financially excluded would include house- holds that are denied credit in spite of their demand. Although credit is the most important component, financial inclusion covers various other financial services such as savings, insurance, payments and remittance facilities by the formal financial system to those who tend to be excluded (GoI. 2006). 


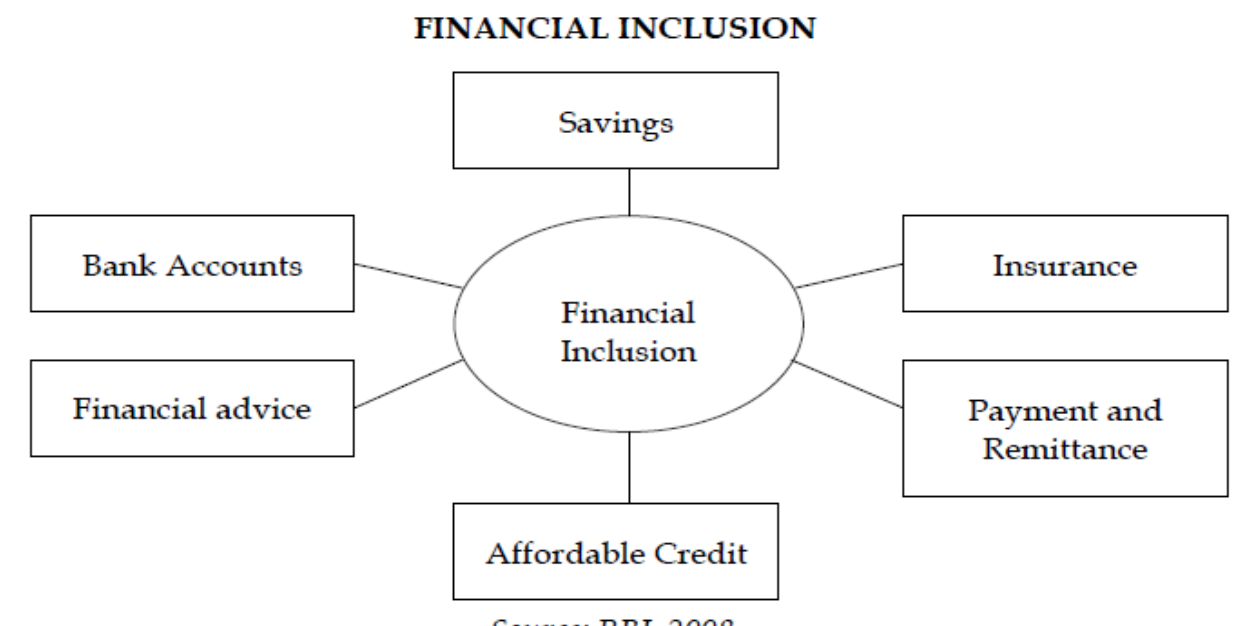

Source: RBI, 2008.

In the case of credit, many households are being exploited by moneylenders at very high interest rates (50 to 60 per cent) and, therefore, these households should not be seen as being financially excluded. It may be true that governments are thinking of using moneylenders as agents. But, the proposal is yet to materialize. Therefore, financial inclusion refers to households accessing institutional credit including commercial banks, cooperative banks, other non- depository financial institutions, mutual funds and other self-help groups, and credible microfinance institutions. It is possible that in order to fulfill targets of financial inclusion, more bank accounts may be opened in the formal system. However, opening a bank account itself is not sufficient. Financial inclusion also refers to making more efforts towards covering small and marginal farmers and vulnerable social groups. A broader definition of inclusion should also focus not only on credit but also on an increase in productivity and sustainability of farmers and other vulnerable groups (S. Dev 2006).

Talking about these comes the question of ways to unite the people in a financially inclusive way. The present policies taken by governments are not well enough to achieve the goal. The figure shows the lag in policies. 


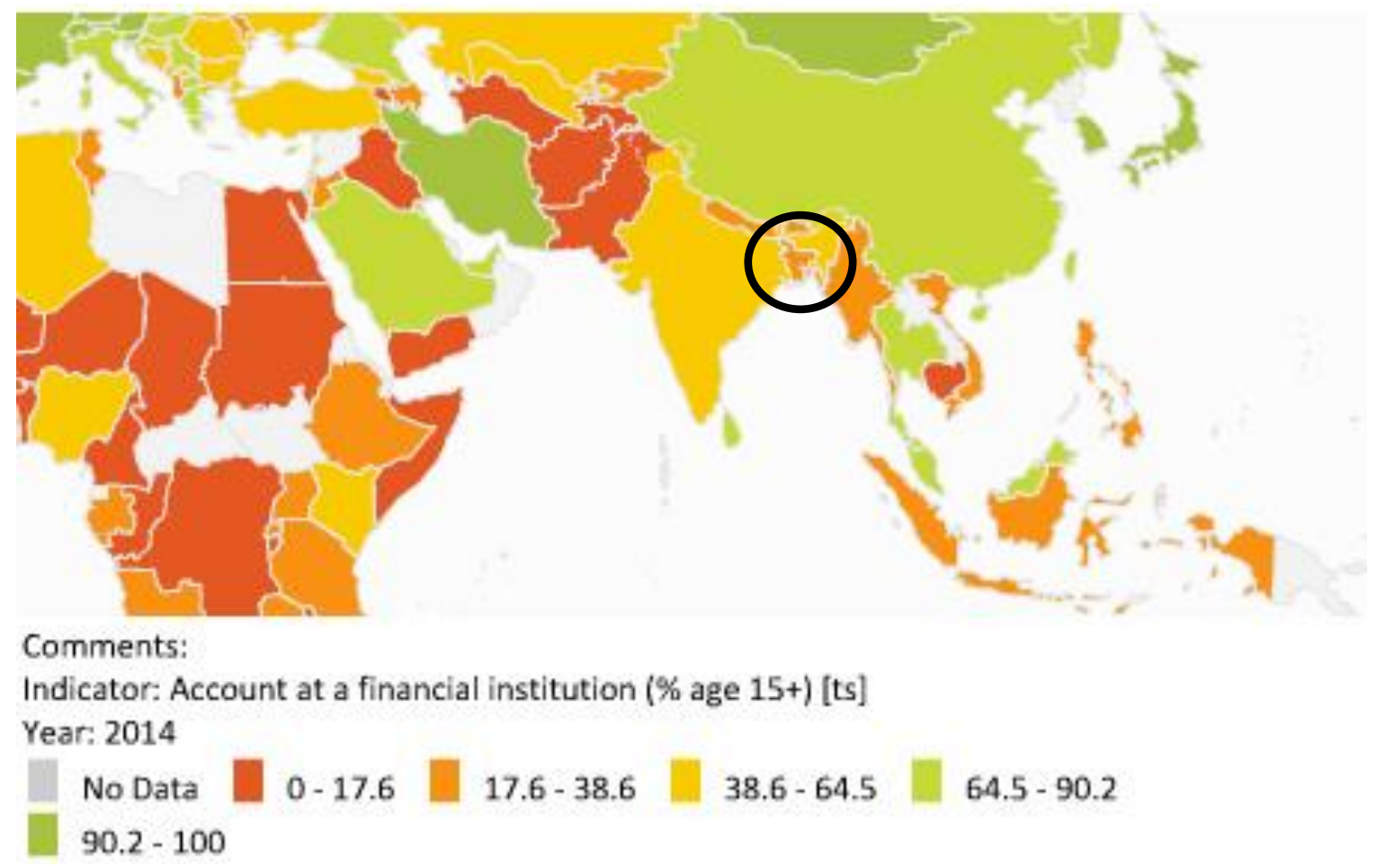

Source: The World Bank

The above figure shows that, only $17.6 \%-38.6 \%$ adults in Bangladesh are presently under the reach of the financial services. This is because the present banks consider the outcome and profitability in a way that, the rural and non-developed areas are always out of the consideration. But these areas consist of the most population of Bangladesh. And only then financial inclusiveness will be successful in Bangladesh when people from these regions will be under formal financial consideration. The study is to recommend ways for the purpose.

Unit banking can be a great solution to the present problem. Unit banks and branch banks offer the same financial services. The key difference between branch banking and unit banking is that while branch bank operates through branches; unit Bank is generally a single branch small bank, which provides financial services to the local community (Farlex Financial Dictionary). Unit system of banking was originated in the United States. In Unit system, the size of banks is small as compared to branch banking. Due to small scale of operations and quick decisions, the work is more efficient. These banks are involved in developmental works in the areas of operations (Farlex Financial Dictionary). 
But there's a bit problem with this system. Unit banks, which loan and borrow from the same groups of people, are more prone to failure in a financial crisis, so much so that some economists believe the Great Depression was made worse by the widespread existence of unit banking. The management enjoys more autonomy and thus more discretionary powers. However, due to single units, the risk is not distributed or diversified. It may however encourage outside local influences (GKToday). In order to have a full proof system we need to cut out the odds of the system through effective and efficient policies, and have a specific modified system for ourselves.

Throughout the study the need, feasibility and optimal solution through a modified system of unit banking will be discussed.

\section{Methodology}

This exploratory-descriptive study is primarily based on secondary data and published materials. But for presenting a thorough view, primary data from different statistical bank is also used. Also the comments and suggestions of planners, policymakers and specialists were taken into consideration.

Overall it is a qualitative study to imply policies against the research problem basing on available literature.

\section{Benefits of the study}

The study indicates to a major economic problem of present Bangladesh. The problem financial exclusion is not something negligible. The study intends to find the root and come to a solution with proper policies and strategies. The study will help the researchers, policymakers and other academics to look at the scenario in an accumulated form. Also it will help them develop their own policies in order to address the problem, as there's always a room for further research.

\section{Financial Inclusion}

Financial inclusion has emerged as a tool to achieve inclusive growth for poverty reduction since 2005. Studies indicate that a positive correlation exists between financial development and economic growth. Current development theories suggest that greater financial inclusion can have a positive impact on the lives of the poor. Access to structured financial services is vital for 
facilitating constant economic growth and thus sustainable development of an economy. Bangladesh, being the fastest growing developing economy, is now vigorously trying to achieve a strong Inclusive Financial system to reduce economic vulnerabilities of its population. Inclusive financial system not only helps the underprivileged to build asset and give access to borrowing, it also helps the government to monitor any financial system loss.

Financial exclusion refers to the lack of access to financial services. It limits opportunities for employment and enterprise development and imposes a premium on the cost of basic services. Financial exclusion thus makes it difficult to reduce inequalities and alleviate poverty. Financial exclusion is a barrier to economic development. Financially excluded populations include marginal farmers, landless labors, unorganized enterprises, urban slum dwellers, migrants, senior citizens and women. Financial inclusion is thus a high priority policy goal for developing and developed countries in order to ensure stable and equitable economic growth.

Almost half of the Bangladesh's adult population in un-banked - most of those who do have a bank account only use it to receive transfer payments and not for 'banking'. This financial exclusion deprives the rural population of the financial services needed to attain financial resilience and restricted access to capital. While a large number of un-banked population enjoy mobile money transfer services, like elsewhere in the world, mobile based savings and credit services have not gained popularity. The root causes for the uneven coverage of financial facilities are manifold:

- Reaching rural population with branch is not cost-effective.

- It is difficult for rural, especially illiterate population, to take advantage of traditional banking that requires a lot of paper work.

- Lack of appropriate financial products for the poor.

- Lack of awareness among population is also responsible for low penetration.

- Present legal framework is aligned to support traditional banking only.

\section{Economic Outcome of Financial Inclusion}

Financial Inclusion is an important tool for attacking poverty. There are three dimensions of attack on poverty: 
1. Creating opportunities for poor to improve their lives.

2. Empowering the poor to demand more responsive state and social institutions.

3. Providing the poor security- to cope with risk. Financial Inclusion is important on all three dimensions- opportunity, empowerment and security.

Financial inclusion is good for all the stakeholders. It is-

1. Good for the poor: Opportunity to improve their incomes and their quality of life.

2. Good for the banks: Steady low cost savings, portfolio diversification etc.

3. Good for the government: Powerful tool of poverty reduction, it also cuts down leakage.

4. Good for the economy: savings of the poor into the formal financial sector.

It is win-win for the poor, banks, government and economy. It is not just a public good but a merit good.

\section{Why Financial Exclusion is bad for Economy?}

Financial exclusion is a current policy concern because it creates financial problems in the following ways:

- Exclusion from affordable loans leaves people who need to borrow money with no option but to use high-interest credit.

- A lack of insurance and savings makes families vulnerable to financial crises following unexpected events such as burglary or flooding. A lack of savings can lead to poverty in old age.

- Many employers will only pay wages into a bank account.

- Cheque cashing agencies may charge 7 to 9 per cent of the value of the cheque plus a fee for the transaction.

- Not having a bank account with a direct debit facility excludes people from this method of paying bills. Most utility suppliers charge more for using other methods of payment, such as pre-payment meters, pay-point cards in convenience stores, postal orders or cash. And, also these modes cause extra payment of charges for the service.

Financial exclusion reinforces social exclusion. It is not just an individual problem: a whole community can suffer from under-investment in financial services. Conversely, financial inclusion significantly contributes to a route out of poverty. 


\section{Scenario of Financial Inclusion in Bangladesh}

Bangladesh has been ranked 16th of 21 countries on its financial and digital inclusion efforts, according to the 2015 Brookings Financial and Digital Inclusion Project (FDIP) report.

While Bangladesh has demonstrated its commitment to providing access to qualify financial services for the under-resourced through a responsive regulatory environment and emphasis on digital financial services, further works remain, said the report. It said an early leader in mobile financial services (MFS), bKash, provides a useful snapshot of mobile money emergence and operation. Bkash approach was a valuable since unlike many mobile companies; bKash is not a mobile network operator and therefore did not have a pre-existing customer base.

\begin{tabular}{|c|c|}
\hline \multicolumn{2}{|l|}{ BANGLADESH: FINANCIAL INCLUSION DATA } \\
\hline POPULATION, TOTAL & $159,077,513$ \\
\hline GDP PER CAPITA, PPP (CURRENT INTERNATIONAL \$) & $3,124.4$ \\
\hline GINI INDEX & 32.1 \\
\hline MOBILE CELLULAR SUBSCRIPTIONS & $120,350,497$ \\
\hline ATMS PER 100,000 ADULTS & 6.3 \\
\hline COMMERCIAL BANK BRANCHES PER 100,000 ADULTS & 8.2 \\
\hline ACCOUNT ATA FINANCIAL INSTITUTION (\%AGE 15t) & 29.1 \\
\hline MOBILEACCOUNT (\% AGE 15t) & 2.7 \\
\hline PERCENTAGE OF TOTAL POPULATION COVERED BYMICROINSURANCE & 6.1 \\
\hline BORROWED FROM A FINANCIAL INSTITUTION (\% AGE 15+) & 9.9 \\
\hline BORROWED ANY MONEY IN THE PASTYEAR (\%AGE 15t) & 48.3 \\
\hline SAVED AT A FINANCIAL INSTITUTION (\% AGE 15+) & 7.4 \\
\hline NO DEPOSIT AND NO WITHDRAWAL IN THE PAST YEAR (\%WITH ANACCOUNT, AGE 15+) & 30.4 \\
\hline
\end{tabular}

The policies and measures which have been undertaken so far in Bangladesh in the context of inclusive banking are of course essential and in the right directions and have already started creating positive impacts. Likewise, volume of SME financing (as a tool of financial inclusion) by the banks has increased manifolds. For example, in 2009, BB target for SME financing was only around Tk. 24,000 crore and it increased to around Tk. 75,000 crore in 2013 and moreover, achievement was $115 \%$. Now, SME loans constitute around $30 \%$ of total loans and advances. A lot of entrepreneurs are getting substantial amount of SME loans and every bank has got SME 
dedicated and women dedicated SME desk. One Bangladesh Bank study shows that SME loans have a number of positive impacts on Bangladesh economy in terms of employment creation, improvement of living standards, women empowerment, and contribution to GDP etc. For coordinating and reinforcing the financial inclusion efforts, BB has converted the Agricultural Credit Department into Agricultural Credit and Financial Inclusion Department and created two new departments namely, SME and special Programs Department and Green Banking and CSR department. Finally, all these financial inclusion efforts have direct and indirect effects on the promotion of financial stability of the country.

Technology is also a great enabler that has prompted the governor of BB to adopt strategies and policies on the use of mobile financial services (MFS) for financial inclusion. There are 25 million mobile bank-account holders (almost one-sixth of the total population) and the number is increasing every day. On average, Tk 3.5 billion (approximately US $\$ 45 \mathrm{~m}$ ) is being transacted daily through mobile banking with more than 80 percent of transactions through a single company - bKash Limited. Thirty-seven percent of adults have an account at either a bank or an MFI and, while the number of deposit accounts is growing steadily, nearly $25 \%$ of the adult population is still to be included by deposit and other financial services from regulated financial institutions.

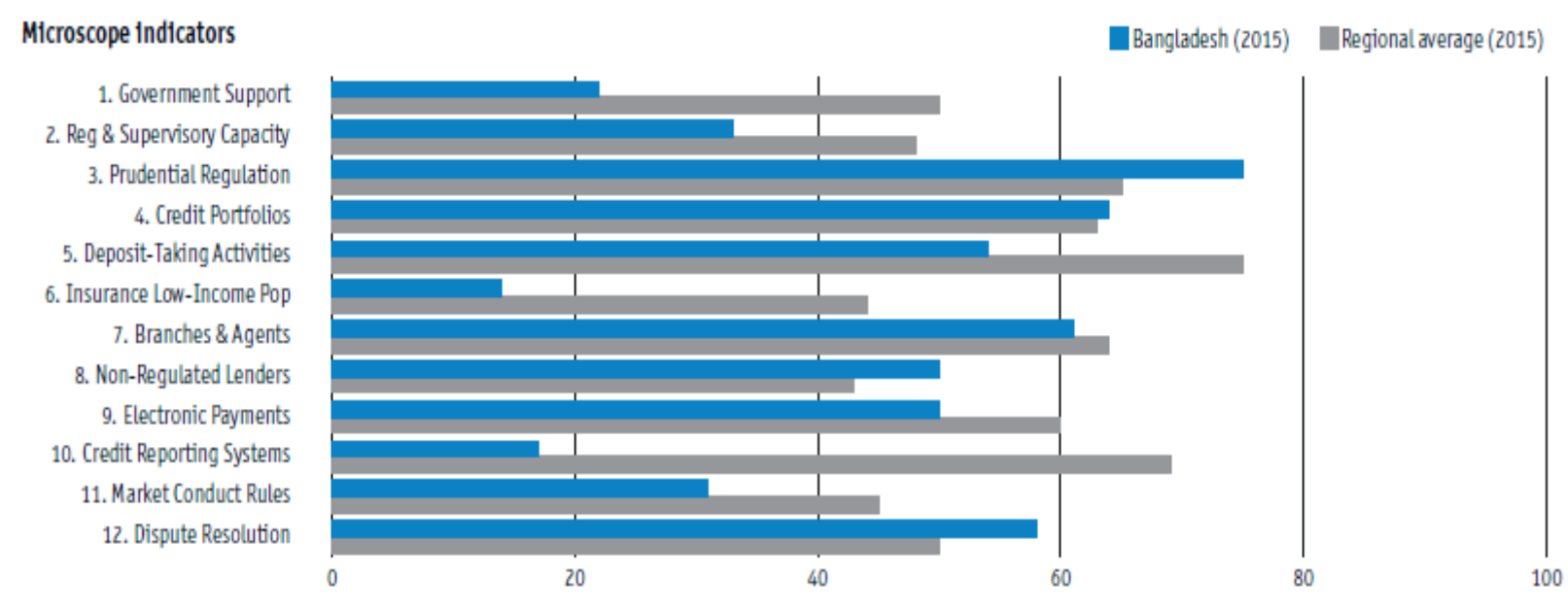

Source: The World Bank 


\section{Contributions of Bangladesh Government \& Bangladesh Bank}

Bangladesh is committed to broadening financial inclusion for the underserved segments of the population. Financial inclusion initiatives are carried out by Bangladesh Bank (BB, the central bank), the Microcredit Regulatory Authority (MRA, the regulator for microfinance institutions, MFIs), and, more recently, the Ministry of Finance (Banks and Financial Institutions Division).

Financial inclusion and developmental-finance campaigns for the underserved are strategies adopted by BB as part of the effort to maintain financial stability in the country.

- Bangladesh Bank, as a regulating body has always motivated and directed financial institutions towards Inclusive Banking policies. Number of banks in the economy is not the only indicator of financial inclusion, rather how well the economic actors can access to the range of diversified financial services at a reasonable cost defines economic inclusion.

- Bangladesh Bank has dedicated its policies to encourage innovation and promote diverse product to reach different segment of population.

- In recent times it has focused extensively on Financial Literacy, to increase participation in formal banking and break psychological barrier of participation. School Banking is the building block of the Financial Literacy plan.

Bangladesh has already earned acclaim during interactions of the central bank governors for its innovative tools to help widen access to banking as part of financial inclusion.

Achievements of the BB have, on many counts, outshone others in this region, in terms of financial inclusion. Some notable measures taken by the Bangladesh Government and Bangladesh bank are:

- By emphasizing fiscal stability and financial inclusion, Bangladesh Bank has been a potent force in the country's economy, pushing lenders to provide credit and loans to farmers, small and medium-sized enterprises (SMEs), and female entrepreneurs.

- Promotion of inclusive financing and environmentally benign green financing are going together in this country, largely because of the BB's initiative for ingraining a socially responsible financing ethos in its financial sector. 
- a2i Phase II took a service delivery approach to address the problem of financial exclusion. Most 'Union Digital Centers' offer Mobile Financial Services and a good number of them offer 'life insurance' services. Approximately 100,000 people take mobile financial services from Union Digital Centres per year and has opened around 3,700 life insurance schemes. More recently, a2i started piloting a 'transfer management system' in one district to digitally manage payment of 6 different public transfers (social safety net) to the beneficiaries.

- Bangladesh Bank introduced a service that allows children to open a savings account with participating banks for as little as 10 Taka (7p). With a minimum deposit of Tk. 10 taka and a compound interest rate of $10 \%$, this product is ideal for the street children it means to serve. Children above 18 with accounts also have an option to take a loan from the same bank if they want to do business or go to school.

\section{Problems Remain}

After all these policies, steps and strategies, the problem remains as it is. The challenges and barriers to the issue are as follows:

1. The inclusive banking measures are bank-led and regulatory driven. These are not really spontaneous initiatives on the part of banks and financial institutions, without which sustainability of inclusive banking cannot be established.

2. The measures so far taken are still not fully able to address the demand side problems of the financially excluded sections of the population. Financial exclusion is not only a supply - side problem.

3. Although access to financial services is relatively high in the country, literacy levels, especially among the poor, remain a challenge.

4. In many cases, people may not be aware of the available services or how to access them.

5. To enable the currently unbanked poor and low income population access financial services from the formal financial system, the development of appropriate financial products is necessary. This requires targeted studies of the demand side. 
6. Promoting technological and institutional innovations as a means could expand the financial system access and usage; however, less than four people per 1,000 population in the country are using credit cards identifying the technological and infrastructural weaknesses.

7. Other barriers include lack of proper documentation, inadequate financial literacy or education, high requirement of minimum balance, low income, lack of suitable product structure of banks and micro-financial institutions (MFIs), high cost of product and absence of credit bureau and insurance of MFI borrowers.

\section{Unit Banking: A Strategic View}

Unit banking has one office. It operates for providing banking services carried on by individual banks without branches or corporate relationships with other banks. Generally, limited banking services are offered to customers by unit banking organization. Although unit banking organization has one banking office, it can spread cash counters in market place such as walk-in windows, automated teller machines, retail store point-of-sale terminals that are linked to the bank's

computer

system.

Unit banking is the oldest kind of banking organization most common in the world banking today. One reason for the comparatively large number of unit banks is the rapid formation of new banks. It can be established easily even in an age of electronic banking and mega mergers among industry leaders. Many customers still seem to prefer small banks, which get to know their customers well and often provide personalized services.

\subsection{Advantages of Unit Banking}

Following are the main advantages of unit banking:

\section{Efficient Management}

One of the most important advantages of unit banking system is that it can be managed efficiently because of its size and work. Co-ordination and control becomes effective. There is no communication gap between the persons making decisions and those executing such decisions.

\section{Better Service}


Unit banks can render efficient service to their customers. Their area of operation being limited, they can concentrate well on that limited area and provide best possible service. Moreover, they can take care of all banking requirements of a particular area.

\section{Close Customer-banker Relations}

Since the area of operation is limited the customers can have direct contact. Their grievances can be redressed then and there.

\section{No Evil Effects Due to Strikes or Closure}

In case there is a strike or closure of a unit, it does not have much impact on the trade and industry because of its small size. It does not affect the entire banking system.

\section{No Monopolistic Practices}

Since the size of the bank and area of its operation are limited, it is difficult for the bank to adopt monopolistic practices. Moreover, there is free competition. It will not be possible for the bank to indulge in monopolistic practices.

No Risks of Fraud

Due to small size of the bank, there is stricter and closer control of management. Therefore, the employees will not be able to commit fraud.

\section{Closure of Inefficient Banks}

Inefficient banks will be automatically closed as they would not be able to satisfy their customers by providing efficient service.

\section{Local Development}

Unit banking is localised banking. The unit bank has the specialised knowledge of the local problems and serves the requirement of the local people in a better manner than branch banking. The funds of the locality are utilised for the local development and are not transferred to other areas.

\section{Promotes Regional Balance}

Under unit banking system, there is no transfer of resources from rural and backward areas to the big industrial and commercial centres. This tends to reduce regional imbalance. 


\subsection{Disadvantages of Unit Banking}

\section{No Economies of Large Scale}

Since the size of a unit bank is small, it cannot reap the advantages of large scale viz., division of labor and specialization.

\section{Lack of Uniformity in Interest Rates}

In unit banking system there will be large number of banks in operation. There will be lack of control and therefore their rates of interest would differ widely from place to place. Moreover, transfer of funds will be difficult and costly.

\section{Lack of Control}

Since the number of unit banks is very large, their co-ordination and control would become very difficult.

\section{Risks of Bank's Failure}

Unit banks are more exposed to closure risks. Bigger unit can compensate their losses at some branches against profits at the others. This is not possible in case of smaller banks. Hence, they have to face closure sooner or later.

\section{Limited Resources}

Under unit banking system the size of bank is small. Consequently its resources are also limited. Hence, they cannot meet the requirements of large scale industries.

\section{Unhealthy Competition}

A number of unit banks come into existence at an important business centre. In order to attract customers they indulge in unhealthy competition.

\section{Wastage of National Resources}

Unit banks concentrate in big metropolitan cities whereas they do not have their places of work in rural areas. Consequently there is uneven and unbalanced growth of banking facilities.

\section{Local Pressure}

Since unit banks are highly localised in their business, local pressures and interferences generally disrupt their normal functioning. 


\section{Branch Banking VS Unit banking}

Unit banking refers to a bank that is a single, usually small bank that provides financial services to its local community. A unit bank is independent and does not have any connecting banks branches - in other areas. Branch banking refers to a bank that is connected to one or more other banks in an area or outside of it; to its customers, this bank provides all the usual financial services but is backed and ultimately controlled by a larger financial institution.

\begin{tabular}{|c|c|c|}
\hline & Branch Banking & Unit Banking \\
\hline About & $\begin{array}{l}\text { A bank that is connected to one or } \\
\text { more other banks in an area or } \\
\text { outside of it. Provides all the usual } \\
\text { financial services but is backed and } \\
\text { ultimately controlled by a larger } \\
\text { financial institution. }\end{array}$ & $\begin{array}{l}\text { Single, usually small bank that } \\
\text { provides financial services to its local } \\
\text { community. Does not have other } \\
\text { bank branches elsewhere. }\end{array}$ \\
\hline Stability & $\begin{array}{l}\text { Typically very resilient, able to } \\
\text { withstand local recessions (e.g., a bad } \\
\text { harvest season in a farming } \\
\text { community) thanks to the backing of } \\
\text { other branches. }\end{array}$ & $\begin{array}{l}\text { Extremely prone to failure when } \\
\text { local economy struggles. }\end{array}$ \\
\hline $\begin{array}{l}\text { Operational } \\
\text { Freedom }\end{array}$ & Less & More \\
\hline Legal History & $\begin{array}{l}\text { Restricted or prohibited for most of } \\
\text { U.S. history. Allowed in all } 50 \text { states } \\
\text { following the Riegle-Neal Interstate } \\
\text { Banking and Branching Efficiency } \\
\text { Act of } 1994 \text {. }\end{array}$ & $\begin{array}{l}\text { Preferred form of banking for most } \\
\text { of U.S. history, despite its tendency } \\
\text { to fail. Proponents were cautious of } \\
\text { branch bankings' concentration of } \\
\text { power and money. }\end{array}$ \\
\hline $\begin{array}{l}\text { Loans } \\
\text { advances }\end{array}$ & $\begin{array}{l}\text { Loans and advances are based on } \\
\text { merit, irrespective of the status. }\end{array}$ & $\begin{array}{l}\text { Loans and advances can be } \\
\text { influenced by authority and power. }\end{array}$ \\
\hline $\begin{array}{l}\text { Financial } \\
\text { resources }\end{array}$ & $\begin{array}{l}\text { Larger financial resources in each } \\
\text { branch. }\end{array}$ & $\begin{array}{l}\text { Larger financial resources in one } \\
\text { branch }\end{array}$ \\
\hline Decision-making & Delay in Decision-making as they & Time is saved as Decision-making is \\
\hline
\end{tabular}




\begin{tabular}{|c|c|c|}
\hline & have to depend on the head office. & in the same branch. \\
\hline Funds & $\begin{array}{l}\text { Funds are transferred from one } \\
\text { branch to another. Underutilization of } \\
\text { funds by a branch would lead to } \\
\text { regional imbalances }\end{array}$ & $\begin{array}{l}\text { Funds are allocated in one branch } \\
\text { and no support of other branches. } \\
\text { During financial crisis, unit bank has } \\
\text { to close down. Hence lead to regional } \\
\text { imbalances or no balance growth }\end{array}$ \\
\hline Cost of supervision & High & Less \\
\hline $\begin{array}{l}\text { Concentration of } \\
\text { power in the hand } \\
\text { of few people }\end{array}$ & Yes & No \\
\hline Specialization & $\begin{array}{l}\text { Division of labor is possible and } \\
\text { hence specialization possible }\end{array}$ & $\begin{array}{l}\text { Specialization not possible due to } \\
\text { lack of trained staff and knowledge }\end{array}$ \\
\hline Competition & High competition with the branches & Less competition within the bank \\
\hline Profits & Shared by the bank with its branches & Used for the development of the bank \\
\hline $\begin{array}{l}\text { Specialized } \\
\text { knowledge of the } \\
\text { local borrowers }\end{array}$ & $\begin{array}{l}\text { Not possible and hence bad debts are } \\
\text { high }\end{array}$ & Possible and less risk of bad debts \\
\hline $\begin{array}{l}\text { Distribution of } \\
\text { Capital }\end{array}$ & $\begin{array}{l}\text { Proper distribution of capital and } \\
\text { power. }\end{array}$ & $\begin{array}{l}\text { No proper distribution of capital and } \\
\text { power. }\end{array}$ \\
\hline Rate of interest & $\begin{array}{l}\text { Rate of interest is uniformed and } \\
\text { specified by the head office or based } \\
\text { on instructions from RBI. }\end{array}$ & $\begin{array}{l}\text { Rate of interest is not uniformed as } \\
\text { the bank has own policies and rates. }\end{array}$ \\
\hline Deposits and assets & $\begin{array}{l}\text { Deposits and assets are diversified, } \\
\text { scattered and hence risk is spread at } \\
\text { various places. }\end{array}$ & $\begin{array}{l}\text { Deposits and assets are not } \\
\text { diversified and are at one place, } \\
\text { hence risk is not spread. }\end{array}$ \\
\hline
\end{tabular}

\section{History and Origin of Unit Banking in US}

Unit banking was the norm in the United States until well into the twentieth century. Even in the antebellum period, before federal restrictions limited branching, there was little interest in branching, at least in the Northeast, and operating branch bank networks posed serious 
challenges. The antebellum branch banking networks formed in a number of Western and Southern states of USA during the antebellum period appear to be an important exception.

Unit system of banking was originated in the United States. Though unit banking was known to cause economic problems by as early as the 1920s, the McFadden Act of 1927 specifically banned interstate branch banking. Unit banking was a topic of discussion again during the development of the 1933 Banking Act, but legal restrictions on branch banking ultimately remained. Proponents of unit banking continued to fear the concentration of wealth and power that comes with branch banking.

The banks in the West and some of the Border States of USA have hybrid structures that combined features of unit and branch banking. One factor in the use of this organizational form appears to have been a desire to expand access to credit facilities.

\section{6. "Modified Unit Banking" for Bangladesh}

All the remaining problems regarding the Unit Banking System are because of some of its shortcomings. For implementing the system in our country, the system needs a slight modification to cope in our economic condition and address our need without hampering the surroundings. The modified features should be-

1. The Units should be allowed to have a corporate relation with other banks.

2. The Units will be directly regulated by Bangladesh Bank through its specified agent in all the divisions.

3. Bangladesh Government should take direct initiatives in founding the Units. It's even better if the Units are being nationalized.

4. Bangladesh Government should provide regulatory easiness in founding the Units.

5. The regions without the reach of formal financial coverage (financially vulnerable) will have the priority to have the Units at the very first moment of the action.

6. The Units should perform at "Union Parisad" level.

7. The metropolitan cities will be out of the reach of the Units at the primary level.

8. Bangladesh Bank will have a different regulation and policy for the Units.

9. The Units will be given permission to perform all the activities of Commercial Banks.

10. No Unit will be allowed to perform out of its specified boundary. 


\section{Policy Recommendations for Implication}

The study's recommendations to money and debt advice services and financial capability initiatives were:

- To realize the precise necessities of the target group in terms of where, when and how to provide support, and the areas to be covered.

- To make cross-referrals, recognizing that financial exclusion may be only one of several problems faced by an individual.

Recommendations for central, regionalized and local government departments were:

- To supply more confident, long-term funding to money and debt counsel and financial skill schemes. This will ensure that expert personnel are not wasted to the sector, and acknowledge the long-term character of clients' necessity.

- To carry on investing in the financial training of guidance workers, mainly those working mostly with a definite vulnerable client group.

- To ensure that the current government pushes for generic financial advice is sufficiently targeted, since the most successful projects are tailored to clients' circumstances.

- Continue to monitor the impact of technological, macro-economic and demographic changes on access to financial services by the specific vulnerable groups identified in this report.

Recommendations for the financial services industry were:

- When planning services, consult those groups who are likely to be financially excluded so as to understand their needs.

- Ensure that consumers receive clear, simple and understandable information.

\section{Conclusion}

Financial exclusion reinforces social exclusion. It is not just an individual problem: a whole community can suffer from under-investment in financial services. Conversely, financial inclusion significantly contributes to a route out of poverty. So, we need to address the issue with our full concentration. Not only one policy can be the only full proof solution. It requires further research and study. Whatever needed to be done to meet the issue should be done fast to ensure a better economic future for Bangladesh. 


\section{Reference}

1. Ahmed, H. (2009) "10 barriers to financial inclusion in Bangladesh identified". Available at: http://print.thefinancialexpress-bd.com/old/more.php?news_id=95415\&date=2012-01-22 (Accessed: 10 May 2016).

2. Atiur Rahman (2015). "Financial Inclusion Bolstering Inclusive Economic Growth in Bangladesh", Bangladesh Bank.

3. Atiur Rahman (2015). "Financial Inclusion as a Tool for Combating Poverty- The Bangladesh Approach”, Bangladesh Bank.

4. Aguirre, Ernesto, Denise Dias, and Klaus Prochaska (2008). "Diagnostic Report on the Legal and Regulatory Environment for Branchless Banking in Colombia." Washington: CGAP.

5. Banco do Nordeste do Brasil (2010). "Background" (www.bnb.gov.br/Content/aplicacao/O_Banco/Historico_eng/gerados/hist_principal.asp).

6. Banerjee, Abhijeet, and others (2009). "The Miracle of Microfinance? Evidence from a Randomized Evaluation." Working paper. MIT, Department of Economics and Abdul Latif Jameel Poverty Action Lab.

7. Bank for International Settlements (2010). "Macroprudential Policy and Addressing Procyclicality." In 80th Annual Report, chapter 7. Basel.

8. Bankable Frontier Associates (2009). "Key Issues in Financial Inclusion Measurement for Regulators: Survey Design and Implementation.” Commissioned draft working paper. Bangkok: Alliance for Financial Inclusion.

9. Beck, Thorsten, and Augusto de la Torre (2006). "The Basic Analytics of Access to Financial Services." Policy Research Working Paper 4026. Washington: World Bank.

10. Beck, Thorsten, Asli Demirgüç-Kunt, and Ross Levine (2004). "Finance, Firm Size, and Growth.” Working Paper W10983. Cambridge, Mass.: National Bureau of Economic Research.

11. Beck, Thorsten, Asli Demirgüç-Kunt, and Vojislav Maksimovic (2004). "Bank Competition and Access to Finance: International Evidence." Journal of Money, Credit, and Banking 36, no. 3 (part 2): 627-48.

12. Beck, Thorsten, and others (2008). "Finance, Firm Size, and Growth."Journal of Money, Credit and Banking 40, no. 7: 1379-405. 
13. Carbo, S., E. P. M. Gardener, P. Molyneux (2005), Financial Exclusion, Palgrave MacMillan.

14. Chaia, Alberto, and others (2009). "Half the World Is Unbanked." Framing Note. New York: Financial Access Initiative (October).

15. Chatain, Pierre Laurent, and others (2008). "Integrity in Mobile Phone Financial Services." Working Paper 146. Washington: World Bank.

16. Christen, Robert Peck, Timothy R. Lyman, and Richard Rosenberg (2003). "Microfinance Consensus Guidelines: Guiding Principles on Regulation and Supervision of Microfinance." Washington: CGAP.

17. Claessens, Stijn, Patrick Honohan, and Liliana Rojas-Suarez (2009). "Policy Principles for Expanding Financial Access: Report of the CGD Task Force on Access to Financial Services.” Washington: Center for Global Development.

18. Conroy, J. (2005), APEC And Financial Exclusion: Missed Opportunities For Collective Action?, Asia-Pacific Development Journal , 12(1), June 2005.

19. Consultative Group to Assist the Poor (CGAP) (2009). Financial Access 2009: Measuring Access to Financial Services around the World. Washington.

20. Demirgüç-Kunt, Asli, Thorsten Beck, and Patrick Honohan (2008). Finance for All? Policies and Pitfalls in Expanding Access. World Bank Policy Research Report. Washington: World Bank (http://go.worldbank.org/HNKL9ZHO50).

21. Dupas, Pascaline, and Jonathan Robinson (2009). "Savings Constraints and Microenterprise Development: Evidence from a Field Experiment in Kenya." Working Paper 14693. Cambridge, Mass.: National Bureau of Economic Research.

22. Economist Intelligence Unit (2009). Global Microscope on the Microfinance Business Environment. London: Economist Group.

23. Eisner, Marc Allen, Jeff Worsham, and Evan J. Ringquist (2006). Contemporary Regulatory Policy. New York: Lynne Rienner.

24. Farlex Financial Dictionary. S.v. "Unit Banking." Retrieved April 82016 from http://financial-dictionary.thefreedictionary.com/Unit+Banking

25. Fernando, Nimal A (2009). "The State of Financial Inclusion in Asia: An Overview." Presentation at the AFI Global Policy Forum. Nairobi, September 14 (www.afiglobal.net/downloads/GPF_Nimal_Fernando.pdf). 
26. Financial Action Task Force (FATF) (2008). "Guidance on Capacity Building for Mutual Evaluations and Implementation of the FATF Standards within Low Capacity Countries." Paris: Financial Access Task Force (www.fatf-gafi.org/dataoecd/61/28/40248726.pdf).

27. Financial Sector Deepening Trust (200)9. FinAccess National Survey 2009: Dynamics of Kenya's Changing Financial Landscape (www.fsdkenya.org/finaccess/documents/09-0610_FinAccess_FA09_Report.pdf).

28. Giné, Xavier, and Robert Townsend (2004). "Evaluation of Financial Liberalization: A General Equilibrium Model with Constrained Occupation Choice.” Journal of Development Economics 74, no. 2: 269-307.

29. GKToday (no date) Available at: http://www.gktoday.in/blog/difference-between-branchbanking-and-unit-banking/ (Accessed: 26 April 2016).

30. GoI (2006). 'Union Budget, 2006-07', Ministry of Finance, Government of India.

31. Grameen Bank (2007). Annual Report 2007. Dhaka.

32. Griffin, J, (2014). Bangladesh bank makes financial inclusion for street kids child's play. Available at: http://www.theguardian.com/global-development-professionalsnetwork/2014/nov/12/bangledesh-working-children-bank-accounts (Accessed: 20 April 2016).

33. Griffin, J. (2014) Bangladesh bank makes financial inclusion for street kids child's play. Available at: http://www.theguardian.com/global-development-professionalsnetwork/2014/nov/12/bangledesh-working-children-bank-accounts (Accessed: 10 May 2016).

34. Hannig, Alfred, and Stefan Jansen (2008). "Inclusive Financial System Reforms: What Works, What Doesn't, and Why?" Draft report. Jakarta: Deutsche Gesellschaft für Technische Zusammenarbeit (GTZ).

35. Hawkins, Penelope (2006). "Financial Access and Financial Stability." Paper prepared for the Conference on Central Banks and the Challenge of Development. Bank for International Settlements, Basel, March 14-15.

36. Honohan, Patrick (2004). "Financial Development, Growth and Poverty: How Close Are the Links?" World Bank Policy Research Working Paper 3203.Washington: World Bank (February). 
37. Islam, E. and Al Mamun, S. (2011). Financial inclusion: the role of Bangladesh Bank. Research Department, Bangladesh Bank Head Office, Dhaka.

38. Kumar, Anjali, and others (2006). "Expanding Bank Outreach through Retail Partnerships: Correspondent Banking in Brazil.” Working Paper 85. Washington: World Bank.

39. Levine, Ross. 2005. "Finance and Growth: Theory and Evidence." In Handbook of Economic Growth, vol. 1A, edited by Philip Aghion and Steven N. Durlauf, chapter 12. Amsterdam: Elsevier.

40. Leyshon, A. and N. Thrift (1995). "Geographies of Financial Exclusion: Financial Abandonment in Britain and the United States", Transactions of the Institute of British Geographers, New Series, Vol. 20, No. 3, pp. 312-41.

41. Ltd, I.C. (no date) Financial inclusion. Available at: http://www.itcbd.com/index.php/payment-services/financial-inclusion.html (Accessed: 1 May 2016).

42. Makanjee, Maya (2009). "Financial Inclusion in Africa." Presentation at the Alliance for Financial Inclusion Global Policy Forum. Nairobi, September 15.

43. Mas, Ignacio, and Hannah Siedek (2008). "Banking through Networks of Retail Agents." Focus Note 47. Washington: CGAP.

44. Mohan, Rakesh (2006), Economic Growth, Financial Deepening and Financial Inclusion, Address at the Annual Bankers' Conference 2006, Hyderabad on November 3, 2006. <http://rbidocs.rbi.org.in/rdocs/Speeches/PDFs/73697.pdf>

45. Mustafa K. Mujeri (2015). "Financial Inclusion of the Poor in Bangladesh: Challenges and Opportunities", General Economics Division of the Planning Commission, Bangladesh Bank and Bangladesh Institute of Development Studies.

46. Orange and Limited, D. (2015). Achieving faster growth in south Asia through financial inclusion | EDITORIAL | the financial express. Available at: http://print.thefinancialexpressbd.com/2015/06/15/96593 (Accessed: 8 May 2016).

47. Otero, Maria, and Elisabeth Rhyne (1994). "Financial Services for Microenterprises: Principles and Institutions." In The New World of Microenterprise Finance, edited by Maria Otero and Elizabeth Rhyne, pp. 11-26. Hartford, Conn.: Kumarian Press.

48. Pande, Rohini, and R. Burgess (2005). “Can Rural Banks Reduce Poverty? Evidence from the Indian Social Banking Experiment.” American Economic Review 95, no. 3: 780-95. 
49. reserved, all rights (2013) Digital financial inclusion. Available at: http://www.a2i.pmo.gov.bd/content/digital-financial-inclusion (Accessed: 10 May 2016).

50. S. Mahendra Dev (2006). "Financial Inclusion: Issues and Challenges", Economic and Political Weekly, Vol. 41, No. 41 (Oct. 14-20, 2006), pp. 4310-4313.

51. The Microcredit Regulatory Authority, Bangladesh (2014). "The Use of Financial Inclusion Data Country Case Study: BANGLADESH”

52. Towards financial inclusion (2015) Available at: http://www.thedailystar.net/supplements/24th-anniversary-the-daily-star-part-1/towardsfinancial-inclusion-73277 (Accessed: 3 May 2016).

53. Tribune, D. (no date) BD ranks 16 th in Brookings financial inclusion. Available at: http://www.dhakatribune.com/business/2015/sep/20/bd-ranks-16th-brookings-financialinclusion (Accessed: 10 May 2016).

54. UN Capital Development Fund and UN Department of Economic and Social Affairs (2006). Building Inclusive Financial Sectors. New York.

55. Young, Robin, and Robert Vogel (2005). "State-Owned Retail Banks (SORBs) in Rural and Microfinance Markets: A Framework for Considering the Constraints and Potential." U.S. Agency for International Development. 